\title{
Heparin-like inhibitor of blood coagulation in normal newborn
}

Citation for published version (APA):

Muller, A. D., van Doorm, J. M., \& Hemker, H. C. (1977). Heparin-like inhibitor of blood coagulation in normal newborn. Nature, 267(5612), 616-617. https://doi.org/10.1038/267616a0

Document status and date:

Published: 16/06/1977

DOI:

10.1038/267616a0

Document Version:

Other version

\section{Please check the document version of this publication:}

- A submitted manuscript is the version of the article upon submission and before peer-review. There can be important differences between the submitted version and the official published version of record.

People interested in the research are advised to contact the author for the final version of the publication, or visit the DOI to the publisher's website.

- The final author version and the galley proof are versions of the publication after peer review.

- The final published version features the final layout of the paper including the volume, issue and page numbers.

Link to publication

\footnotetext{
General rights rights.

- You may freely distribute the URL identifying the publication in the public portal. please follow below link for the End User Agreement:

www.umlib.nl/taverne-license

Take down policy

If you believe that this document breaches copyright please contact us at:

repository@maastrichtuniversity.nl

providing details and we will investigate your claim.
}

Copyright and moral rights for the publications made accessible in the public portal are retained by the authors and/or other copyright owners and it is a condition of accessing publications that users recognise and abide by the legal requirements associated with these

- Users may download and print one copy of any publication from the public portal for the purpose of private study or research.

- You may not further distribute the material or use it for any profit-making activity or commercial gain

If the publication is distributed under the terms of Article $25 \mathrm{fa}$ of the Dutch Copyright Act, indicated by the "Taverne" license above, 


\section{Heparin-like inhibitor of blood coagulation in normal newborn}

THE level of the blood coagulation factors in the newborn is known to be markedly lower than that in the adult. Generally this is attributed to a lack of synthetic capacity of the liver and a deficiency in vitamin $\mathrm{K}$. We describe here a re-investigation of this problem making use of recently developed methods that determine both the coagulation factors and the abnormal proteins induced by vitamin $\mathrm{K}$ absence (PIVKAs). We found low coagulation factor activity in the newborn but no evidence for vitamin $\mathrm{K}$ deficiency. In more than half the samples a hitherto unrecognised inhibitor of blood coagulation could be demonstrated. At $3 \mathrm{~d}$ of age this inhibitor was found in all babies investigated. On the basis of its properties in blood coagulation tests the inhibitor could not be distinguished from heparin.

In 43 healthy newborns a $20-\mathrm{cm}$ piece of umbilical cord was clamped directly after birth and $9 \mathrm{ml}$ of blood was withdrawn by puncture from the vena umbilicalis into a polypropylene syringe containing $1 \mathrm{ml}$ of a solution containing HEPES $0.3 \mathrm{M}$, trisodium citrate $0.1 \mathrm{M}$, sodium azide $15 \mathrm{mM}$, Trasylol (Bayer) $50 \mathrm{U}, p \mathrm{H}$ 7.3. This mixture effectively prevents fibrinolysis. Plasma was obtained by centrifugation and spun platelet poor by a second centrifugation $\left(30 \mathrm{~min} 4{ }^{\circ} \mathrm{C}, 20,000 \mathrm{~g}\right)$. It was frozen in 1-ml aliquots and stored at $-20^{\circ} \mathrm{C}$ until further use. In these plasmas we determined clotting factors $\mathrm{V}$, VII, and $\mathrm{X}$ and prothrombin by a one-stage procedure and prothrombin also by a twostage procedure (Table 1). Experimental methods were as described in ref. 1.

In 27 of the 43 plasmas the disappearance rate of thrombin in the two-stage prothrombin assay was significantly ( $>5$ times) greater than in normal human adult plasma. In the 16 others it was no more than 1.8 times greater than normal. On the basis of this observation we divided the plasma in an inactivated and a non-inactivated group. We found no significant differences in antithrombin III, $\alpha_{1}$-antitrypsin, $\alpha_{2}$-macroglobulin, antiplasmin, $\mathrm{C}_{1}$-esterase inhibitor and inter- $\alpha$-trypsin inhibitor activities between inactivated and non-inactivated plasma samples: we therefore conclude that none of these proteins are responsible for the inactivation. No fibrinogen degradation products could be detected in either of the plasmas. Pooled inactivated and pooled non-inactivated plasma was diluted 20 -fold with

Table 1 Determination of clotting factors in cord blood

\begin{tabular}{llrr}
\hline \multicolumn{1}{c}{ Factor } & & \multicolumn{2}{c}{ Mlood activity $(\%)$} \\
& & I & Non-I \\
Antithrombin III & CIE & $62 \pm 8$ & $61 \pm 12$ \\
$\alpha_{1}$-Antitrypsin & CIE & $74 \pm 12$ & $81 \pm 15$ \\
$\alpha_{2}$-Macroglobulin & CIE & $104 \pm 20$ & $110 \pm 16$ \\
Antiplasmin & CIE & $49 \pm 9$ & $49 \pm 8$ \\
C $_{1}$ esterase inhibitor & CIE & $53 \pm 11$ & $58 \pm 12$ \\
Inter- $\alpha$-trypsin & CIE & $64 \pm 14$ & $65 \pm 13$ \\
Inhibitor & & $51 \pm 12$ & $47 \pm 10$ \\
II & one-stage & $48 \pm 12$ & $47 \pm 11$ \\
II & two-stage & $54 \pm 11$ & $49 \pm 9$ \\
II & Echis Carinatus venom & $48 \pm 8$ & $48 \pm 10$ \\
II & staphylocoagulase & $53 \pm 15$ & $50 \pm 16$ \\
II & CIE & & \\
V & one-stage & $43 \pm 12$ & $44 \pm 10$ \\
VII & one-stage & $31 \pm 15$ & $30 \pm 7$ \\
X & one-stage & & \\
\hline
\end{tabular}

Values are means $t$ s.d. of the blood activities as \% of pooled blood from 30 normal adults. I, group showing rapid thrombin inactivation $(n=27)$; Non-I, group showing normal thrombin inactivation $(n=16)$. CIE, crossed immunoelectrophoresis. distilled water; isoelectric precipitation at $p \mathrm{H} 5.2$ yielded a fraction containing prothrombin but no thrombin inhibitors. In such fractions made from both plasma types, thrombin generated normally and was not inactivated. In the presence of normal plasma the thrombin thus generated inactivated normally. This excluded the possibility that the rapid inactivation was due to an abnormality of the (pro)thrombin molecule in the inactivated plasma.

Both procoagulants and thrombin inactivating proteins in inactivated plasma were precipitated by phosphotungstic acid $(1 / 3$ volume of $10 \%$ phosphotungstic acid in $0.67 \mathrm{~N}$ $\left.\mathrm{H}_{-} \mathrm{SO}_{4}\right)$. After neutralisation and removal of the phosphotungstic acid, the resulting fraction accelerated thrombin inactivation in normal plasma by a factor five to seven, and lost its inactivation enhancing properties on addition of $12 \mu \mathrm{g} \mathrm{ml}^{-1}$ protamine sulphate. No such fraction could be obtained from the non-inactivated plasma. Inactivation of thrombin in inactivated plasma could be prevented by addition of $14 \mu \mathrm{g} \mathrm{ml}^{-1}$ of protamine sulphate whereas such addition had little or no effect on non-inactivated plasma.

Heparin is known to potentiate thrombin inactivation by antithrombin III, to be neutralised by protamine sulphate and not to be precipitated by phosphotungstic acid ${ }^{2}$.

We conclude that the inactivated plasma contains heparin or a substance with heparin-like properties. The source of this substance is presumably in the newborn. It could not be demonstrated in maternal blood or in the perfused placenta. Five children who did not show enhanced inactivation in the cord blood did show this activity in blood taken from the vena cubiti on day 3 of life. The 11 others from the noninactivated group were not tested.

Presumably this heparin-like substance is produced in organs that are hardly perfused before birth, but will have an active circulation afterwards (that is, the lungs). It may serve to prevent thrombosis in these organs. In this context it is interesting to note that complete deficiency of antithrombin has never been observed although several series of (possibly heterozygous) patients with about a half normal amount of antithrombin III have been reported ${ }^{3}$. Complete absence of antithrombin III which would prevent the action of the heparin-like substance might be a lethal condition.

We found no differences between the inactivated and non-inactivated groups in any of the coagulation factors

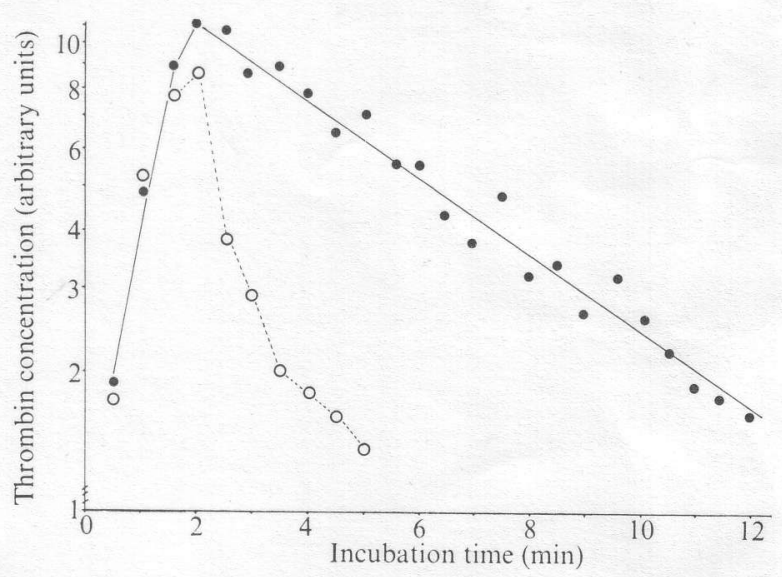

Fig. 1 Thrombin generation and breakdown in pooled newborn plasmas with $(O)$ and without $(O)$ inactivating substance. Reaction mixture: $0.2 \mathrm{ml}$ plasma, $0.1 \mathrm{ml}$ human brain thromboplastin, $1.7 \mathrm{ml} \mathrm{Michaelis} \mathrm{buffer} p \mathrm{H} \mathrm{7.2,1} \mathrm{ml} \mathrm{CaCl}_{2} 33 \mathrm{mM}$. At the times indicated $0.1 \mathrm{ml}$ of the reaction mixture was subsampled into $0.1 \mathrm{ml}$ of $\mathrm{BaSO}_{4}$ adsorbed plasma diluted 1:5 with Michaelis buffer $(p H$ 7.2). From the clotting time obtained the thrombin content was calculated ${ }^{1}$. 
tested. More interesting, there was no discrepancy between the prothrombin contents found with the one-stage and the two-stage assay (Table 1). This indicates that no proteins induced by vitamin $\mathrm{K}$ absence (PIVKAs) are present in the plasma of the newborn ${ }^{4}$. This is corroborated by the fact that neither in the staphylocoagulase test nor in the Echis Carinatus test nor in a one-dimensional immuno electrophoresis an excess of prothrombin activity was observed whereas the PIVKA when present would co-estimate in these tests (Table 1 , ref. 1 ).

We concluded that, contrary to current beliefs, the newborn has no vitamin $\mathrm{K}$ deficiency but is 'anticoagulated' by heparin or a heparin-like substance.
A. D. Muller
J. M. VAN DOORM*
H. C. HeMKer

Department of Biochemistry,

Biomedical Centre,

State University Limburg,

Maastricht, The Netherlands

Received 2 November 1976; accepted 21 February 1977.

*Present address: Department of Obstetrics and Gynaecology, Onze Lieve Vrouwen Gasthuis, Amsterdam, The Netherlands.

1 Bas, B. M., Muller, A. D. \& van der Voort-Beelen, J. M. J. molec. Med. 1, 65-72 (1975)

2 Gastpar, H. Thrombos. Diathes. haemorrh. Suppl. 16, (1965).

Van der Meer, J., Stoepman-v. Dalen, E. A. \& Jansen, J. M. S. J. clin. Path. 26,

Hemker $\mathrm{H} . \mathrm{C} \cdot \mathrm{M}$

C., Muller, A. D. \& Loeliger, E. A. Thrombos. Diathes, haemorrh. 23 633-637 (1970). 